\title{
Ozone-treated Mesquite for Supplementing Steers in West Texas
}

\author{
FRED C. BRYANT, THOMAS MILLS, JOHN S. PITTS, MIKE CARRIGAN, AND ERNIE P. WIGGERS
}

\begin{abstract}
Ozonated-mesquite was compared with cottonseed hulls as the fiber base in supplemental rations fed to growing steers under range conditions. Average daily gains of steers fed the 2 rations for the 2 winter feeding periods were similar. Similarities in concentrations of acetic, propionic, and butyric acids, and acetic:propionic acid ratios between rations indicated no alterations in production of these acids as affected by composition or physical form of the ozonated-mesquite. Therefore, ozonated-mesquite appears to be equal in value to cottonseed hulls as a roughage base in supplemental rations fed to range steers.
\end{abstract}

Mesquite (Prosopis glandulosa) is a rangeland pest that infests millions of acres in the arid Southwest. Attempts to control this woody perennial have included mechanical, pyric, biological, and chemical means. While these methods are effective in managing mesquite, they exclude the use of the tremendous quantity of fiber available in this plant. It has been recently realized that this plant is an untapped reservoir for industrial use or livestock feed. If harvesting and processing becomes economical, all avenues for disposal of the lignocellulose from mesquite should be investigated.

Lignocellulose residues, including wood pulp, have been the focus of livestock feeding experiments for many years. Research has dealt with corn and milo residues (Bolsen et al. 1977, Ward 1978); cereal and grass straws (Durham and Hinman 1979, Church and Champe 1980); soybean residues (Miller et al. 1979); cotton by-products (Arndt et al. 1980); and wood and wood by-products (Dinius and Bond 1975, Lemieux and Wilson 1979).

Many chemical treatments have been applied to increase cellulose digestibility. Some of these included sodium hydroxide (Hendrix and Karn 1976); ammonia (Paterson et al. 1979a); and calcium hydroxide (Paterson et al. 1979b) on crop residues, and sodium hydroxide (Millett et al. 1970); sulfur dioxide (Sherrod et al. 1978); sulphuric acid (Keith and Daniels 1976); irradiation (Kitts et al. 1969); and ozonization (Schuerch 1963) on wood and wood byproducts. Ozonization of mesquite appears to increase cellulose digestion (R.W. Tock, unpublished data; Weakley and Owens 1975).

While most research has been limited to trials in vitro or in vivo with confined animals in drylot, few studies have attempted to evaluate crop or wood residues in supplemental rations for livestock on dry perennial rangeland. The objective of this study was to compare ozonated mesquite with cottonseed hulls as the fiber base in winter supplemental rations for growing range steers. The supplemental rations tested were similar to the range cubes commonly fed to range cattle.

\footnotetext{
At the time of research, authors were assistant professor, student assistant, student assistant, graduate assistant, and graduate assistant in the Department of Range and Wildlife Management, Texas Tech University, Lubbock 79409. Carrigan's present address is P.O. Box 1238, Roswell, N.Mex. 88201 . Wiggers's present address is Ashland Wildlife Research Area, Rt. 2, Ashland, Mo. 65010.

This research was supported in part by line item funds provided by the Texas Legislature entitled "Research in Mesquite Utilization." This is a manuscript \#T-9-333 of the College of Agricultural Sciences, Texas Tech University, Lubbock 79409.

Mention of a product's name in this paper does not constitute a recommendation by Texas Tech University.

Manuscript accepted January 31, 1984.
}

\section{Study Area}

The study area was on 75 ha of native range on the Texas Tech University campus. The soils are deep sandy and clay loams, well drained, and have dcep root zones. Slopes range from $0-3 \%$ (USDA 1979). The pasture was in poor-fair range condition and had dense infestations of mesquite, Mimosa sp. and broom snakeweed (Xanthocephalum sarothrae). Major grasses were blue grama (Bouteloua gracilis) and buffalograss (Buchloe dactyloides).

\section{Methods}

Whole mesquite trees $(>2.5 \mathrm{~m}$ tall) were mechanically harvested with the Texas Tech University Brush Combine No. IV (Ulich 1983) from rangcland on the campus during the summer of 1980. The combine reduced the entire above-ground plant to $1.2-1.5-\mathrm{cm}$ chips. Chips, after air-drying 7-9 days to a moisture content of 5-10\%, were hammermilled through a 6-mm screen. The mesquite meal was ozoned in a continuously stirred tank reactor for 2 hours. Ozonization was accomplished by adding $60 \%$ water, by volume, to approximately $20.4 \mathrm{~kg}$ of mesquite meal in the reactor and passing $0_{3}$ through the mixture. Evidently, water swells the wood lumen allowing $0_{3}$ access to the lignin before attacking the holocelluloses. After ozonization, the meal was dried in a forced-air oven at $60^{\circ} \mathrm{C}$ for 12 hours.

Rations were formulated to provide $25 \%$, by weight, of a fiber base either of cottonseed hulls (control ration) or ozonated mesquite (mesquite ration) (Table 1). Nutrient balancing, particularly

Table 1. Ingredients $(\%)$ used in rations fed to steers as a supplement to range forage.

\begin{tabular}{lcc}
\hline Ingredient & Control & Mesquite \\
\hline Sorghum & 47.2 & 43.2 \\
Fiber & $25.0^{1}$ & $25.0^{2}$ \\
Cottonseed meal & 16.0 & 20.0 \\
Nutri-binder & 10.0 & 10.0 \\
Calcium carbonate & 0.8 & 0.8 \\
Sodium sulphate & 0.5 & 0.5 \\
Trace mineral & 0.5 & 0.5 \\
Vitamins & + & + \\
\hline
\end{tabular}

'Cottonseed hulls

2Processed mesquite pulp

3Protein ( $8 \%$ ), fat (2\%), crude fiber (3\%), ash (3\%)

4Vitamin A(50g/ton@60,000 lu/g), vitamin D ( $1.75 \mathrm{lb} /$ ton @200,000 lu/lb), vitamin E (30 g/ton@ $125,00 \mathrm{lu} / \mathrm{lb})$

crude protein, was accomplished by adding cottonseed meal or sorghum grain. Crude protein contents were 16.2 and $14.8 \%$ for the control and mesquite rations, respectively, in 1980-81 and 15.0 and $14.3 \%$ in 1981-82. A complete nutrient and mineral analysis of the rations was reported by Bryant et al. (1982).

Rations were fed to steers from January through March in 1981 and from November through March in 1981-82. Individual steers were limited to a mesquite or control ration by a Calan Broadbent feeding system (American Calan Inc., Route 4, Northwood, N. H. 03261 ). This system consisted of an electronic key worn around the 
Table 2. Average daily gain (kg/day) of steers supplemented under range conditions with mesquite and control rations.

\begin{tabular}{|c|c|c|c|c|c|c|c|c|c|c|c|}
\hline \multirow[b]{2}{*}{ Ration } & \multicolumn{4}{|c|}{1981} & \multicolumn{7}{|c|}{$1981-82$} \\
\hline & $\mathbf{N}$ & Feb. & Mar. & Mean & $\mathbf{N}$ & Nov. & Dec. & Jan. & Feb. & Mar. & Mean \\
\hline Mesquite & 6 & $0.20 \mathrm{a}$ & $0.12 \mathrm{a}$ & $0.16 \mathrm{a}$ & 7 & $0.41 \mathrm{a}$ & $0.34 \mathrm{a}$ & $0.58 \mathrm{a}$ & $-0.31 \mathrm{a}$ & $0.13 \mathrm{a}$ & $0.23 \mathrm{a}$ \\
\hline Control & 6 & $0.22 \mathrm{a}$ & $0.13 a$ & $0.17 \mathrm{a}$ & 6 & $0.30 \mathrm{a}$ & $0.36 \mathrm{a}$ & $0.28 \mathrm{~b}$ & $-0.70 b$ & $0.37 b$ & $0.23 \mathrm{a}$ \\
\hline
\end{tabular}

"Means in the same column with the same superscript are not different $(P>0.05)$.

neck of a steer which allowed it access to only one feeding bin. The average weight of steers was $250 \mathrm{~kg}$ during both winter feeding periods.

The supplement feeding rate in 1981 was $1.8 \mathrm{~kg} /$ day. The initial rate in 1981-82 was $0.9 \mathrm{~kg} /$ day. This rate was increased to 1.8 $\mathrm{kg}$ /day on 23 December 1981, and then to $3.6 \mathrm{~kg} /$ day on 5 February 1982. The adjustments were necessary because of a depletion in native forage. During both feeding trials, steers were supplemented at 3-day intervals. Steers were weighed approximately every 30 days and average daily weight gain (ADG) was determined.

Four steers receiving the mesquite and 4 receiving the control ration were fistulated for the collection of reticulo-rumen fluids during the 1981-82 feeding period. Approximatley $50 \mathrm{ml}$ of rumen fluids were collected from each steer at the end of November and every 2 weeks thereafter through March. Steers were fasted for 2 hours prior to collection of fluids. Immediately after collection, fluids were placed in a freezer at $-10^{\circ} \mathrm{C}$ and stored there until subsequent analysis. The Vane Dome chromatographic method (AACC Standard Method 04-23) was used to quantify percentage concentrations of acetic, propionic, and butyric volatile fatty acids (VFA) in the reticulo-rumen fluids. Percentage concentrations of these VFA's were the average of two sub-samples of each collection of reticulo-rumen fluids. Fluids were analyzed only for acetic, butyric, and propionic because they are the most important VFA by-products of rumen fermentation, contributing 90 to $96 \%$ of the digestible energy supplied by VFA's (Wilson 1971).

Because of unequal sample sizes, significant differences in ADG were established with the Duncan's multiple range test. VFA concentration means were compared with the $t$ test to determine if significant differences occurred between steers fed the mesquite and control rations.

\section{Results and Discussion}

There was no difference $(P>0.05)$ in the ADG of steers fed the mesquite or control rations, 0.16 vs. $0.17 \mathrm{~kg}$, respectively, in $1980-81$ and 0.23 vs. $0.23 \mathrm{~kg}$ in $1981-82$, when averaged for 2 winter feeding trials (Table 2). The ADG of control steers was slightly higher during each weighing interval in the 1981 feeding trial. Significant differences $(P<0.05)$ were determined in the ADG between ration treatment in the January, February, and March weighing intervals in 1982 , but one ration did not consistantly produce the higher ADG. The monthly differences in ADG are believed to be associated with the depletion of available native forage that occurred during this period. To compensate for the shortage in available forage, the supplemental feeding rate was eventually increased by a factor of 4 by the end of the second winter trial. In March, the increased feeding rate allowed steers on both rations to again gain weight, although the steers on the control ration gained at a significantly $(P<0.05)$ higher rate. The lower performance of steers on both rations because of limited available forage indicated more of the rations should have been fed under these stress conditions. If forage supply is adequate and a higher level of performance is desired, rations could be mixed to supply more crude protein and energy.

Rumen concentrations of acetic, propionic, and butyric acids and acetic:propionic (A:P) ratio were not different $(P>0.05)$ between ration treatments (Table 3). The VFA concentrations are similar to those reported by Olten et al. (1966), for steers receiving a pelleted corn-soy, molasses ration. Topps et al. (1965) reported higher acetic and lower propionic and butyric acid concentrations than those in our study for steers on winter grassland with a carbohydrate plus protein supplement.

The VFA concentrations in the reticulo-rumen fluid are strongly influenced by diet composition and physical form (Newland et al. 1962, Wood and Rhodes 1962 , Weiss et al. 1967). The similar levels of major VFA's between ration treatment suggest that ozonetreated mesquite fiber is comparable to cottonseed hulls as a fiber base in supplemental diets. Further, the relatively low A:P ratio and high concentration of butyric acid indicated the mesquite ration was as efficiently converted to energy as the ration with cottonseed hulls; both rations were apparently converted to energy based on data from Blaxter (1962), Armstrong and Blaxter (1957), and Tonroy and Perry (1974).

Our data suggest ozone-treated mesquite is comparable in value to cottonseed hulls as a fiber base in supplemental rations fed to growing range steers. These results should not be extrapolated to

Table 3. Concentrations (molar \%) of major volatile fatty acids from fistulated steers supplemented under range conditions with mesquite and control rations during the $1981-82$ winter feeding period.

\begin{tabular}{|c|c|c|c|c|c|c|c|c|c|}
\hline \multirow[b]{2}{*}{ Ration } & \multirow[b]{2}{*}{$\mathbf{N}$} & \multirow[b]{2}{*}{ Volatile fatty acid } & \multicolumn{7}{|c|}{ Date } \\
\hline & & & $11-27-81$ & $1-4-82$ & $1-19-82$ & $2-10-82$ & $3-2-82$ & $3-15-83$ & Mean \\
\hline $\begin{array}{l}\text { Mesquite } \\
\text { Control }\end{array}$ & $\begin{array}{l}4 \\
4\end{array}$ & $\begin{array}{l}\text { Acetic acid } \\
\text { Acetic acid }\end{array}$ & $\begin{array}{l}50.2^{1} \\
47.7\end{array}$ & $\begin{array}{l}47.0 \\
45.1\end{array}$ & $\begin{array}{l}43.4 \\
48.3\end{array}$ & $\begin{array}{l}41.4 \\
42.3\end{array}$ & $\begin{array}{l}44.3 \\
40.0\end{array}$ & $\begin{array}{l}38.0 \\
44.0\end{array}$ & $\begin{array}{l}44.1 \\
44.6\end{array}$ \\
\hline $\begin{array}{l}\text { Mesquite } \\
\text { Control }\end{array}$ & $\begin{array}{l}4 \\
4\end{array}$ & $\begin{array}{l}\text { Propionic acid } \\
\text { Propionic acid }\end{array}$ & $\begin{array}{l}26.0 \\
26.6\end{array}$ & $\begin{array}{l}26.6 \\
31.2\end{array}$ & $\begin{array}{l}35.5 \\
27.6\end{array}$ & $\begin{array}{l}34.0 \\
35.6\end{array}$ & $\begin{array}{l}30.2 \\
29.1\end{array}$ & $\begin{array}{l}27.0 \\
28.5\end{array}$ & $\begin{array}{l}29.9 \\
29.8\end{array}$ \\
\hline $\begin{array}{l}\text { Mesquite } \\
\text { Control }\end{array}$ & $\begin{array}{l}4 \\
4\end{array}$ & $\begin{array}{l}\text { Butryic acid } \\
\text { Butryic acid }\end{array}$ & $\begin{array}{l}18.1 \\
20.3\end{array}$ & $\begin{array}{l}23.3 \\
20.8\end{array}$ & $\begin{array}{l}16.8 \\
19.7\end{array}$ & $\begin{array}{l}21.4 \\
19.9\end{array}$ & $\begin{array}{l}20.3 \\
22.5\end{array}$ & $\begin{array}{l}25.0 \\
18.1\end{array}$ & $\begin{array}{l}20.8 \\
20.2\end{array}$ \\
\hline $\begin{array}{l}\text { Mesquite } \\
\text { Control }\end{array}$ & $\begin{array}{l}4 \\
4\end{array}$ & $\begin{array}{l}A: P^{2} \\
A: P\end{array}$ & $\begin{array}{l}1.9 \\
1.8\end{array}$ & $\begin{array}{l}1.8 \\
1.5\end{array}$ & $\begin{array}{l}1.5 \\
1.8\end{array}$ & $\begin{array}{l}1.3 \\
1.2\end{array}$ & $\begin{array}{l}1.5 \\
1.4\end{array}$ & $\begin{array}{l}1.4 \\
1.8\end{array}$ & $\begin{array}{l}1.6 \\
1.6\end{array}$ \\
\hline
\end{tabular}

There were no significant differences $(P>0.05)$ between rations for similar volatile fatty acids concentrations or $A: P$ ratios within dates.

${ }^{2} \mathrm{~A}: \mathrm{P}=$ ratio of acetic to propionic acids. 
range cows in a reproductive physiological status (gestation/lactation). Suitability of ozonated mesquite as a supplement to producing cows needs further investigation. The use of mesquite as a ration base could provide an economical use of its fiber by helping offset the costs associated with its removal from infested grasslands.

\section{Literature Cited}

Armstrong, D.G., and K.L. Blaxter. 1957. The heat increment of steamvolatile fatty acids in fasting sheep. Brit. J. Nutr. 11:247-272.

Arndt, D.L., C.R. Richardson, R.C. Albin, and L.B. Sherrod. 1980. Digestibility of chemically treated cotton plant by-product and effect on mineral balance, urine, volume and pH. J. Anim. Sci. 51:215-223.

Blaxter, K.L. 1962. The energy metabolism of ruminants. Hutchinson and Co., London, England.

Bolsen, K.K., C. Grimes, and J.G. Riley. 1977. Milo stover in rations for heifers and lambs. J. Anim. Sci. 45:377-384.

Bryant, F.C., T. Mills, J.S. Pitts, and M. Carrigan. 1982. Ozone-treated mesquite as the roughage base in range cattle supplemental feed. $p$. GI-G6. In: Proc. Symp. on Mesquite Utilization. H.W. Parker (Ed.). College Agr. Sci., Texas Tech Univ., Lubbock

Church, D.C., and K.A. Champe. 1980. Digestibility of untreated and hydroxide-treated annual ryegrass straw. J. Anim. Sci. 51:20-24.

Dinius, D.A., and J. Bond. 1975. Digestiblity, ruminal parameters, and growth by cattle fed a waste pulp. J. Anim. Sci. 41:629-634.

Durham, R.R., and D.D. Hinman. 1979. Digestibility and utilization of bluegrass straw harvested on three different dates. J. Anim. Sci. 48:464-467.

Hendrix, K.S. and P.H. Karn. 1976. NaOH treatment of ensiled and dry corn residue. J. Anim. Sci. 43:325 (Abstract).

Keith, E.A., and L.B. Daniels. 1976. Acid or alkali-treated hardwood sawdust as a feed for cattle. J. Anim. Sci. 42:888-891.

Kitts, W.D., C.R. Krishnamurti, J.A. Shelford, and J.G. Huffman. 1969. Use of wood and woody by-products as a source of energy in beef cattle rations. Advances in Chemistry Series No. 95:279-297.

Lemleux, P.G., and L.L. Wilson. 1979. Nutritive evaluation of a waste wood pulp in diets for finishing lambs. J. Anim. Sci. 49:342-353.

Miller, B.L., G.C. Fahey, Jr., R.B. Rindsig, L.L. Berger, and W.G. Bottje. 1979. In vitro and in vivo evaluations of soybean residues ensiled with various additives. J. Anim. Sci. 49:1545-1551.
Millett, M.A., A.J. Baker, W.C. Feist, R.W. Mellenberger, and L.D. Satter. 1970. Modifying wood to increase its in vitro digestibility. J. Anim. Sci. 31:781-788.

Newland, H.W., W.T. Magee, G.A. Branaman, and L.H. Blakeslee. 1962. Effects of heat processing and pelleting corn for steers and lambs. J. Anim. Sci. 21:711-715.

Olten, R.R., J. Guttierrez, R.P. Lehmann, and R.E. Davis. 1966. Rumen chemical and microbial characteristics of steers fed a purified and a natural diet. J. Anim. Sci. 25:521-525.

Paterson, J.A., T.J. Klopfenstein, and R.A. Britton. 1979a. Ammonia treatment of corn plant residue. J. Anim. Sci. 48:270. (Abstract).

Paterson, J.A., T.J. Klopienstein, and R.A. Britton. 1979b. The interaction of calcium hydroxide treatment and moisture level of crop residues. J. Anim. Sci. 48:270-271. (Abstract).

Schuerch, C. 1963. Ozonization of cellulose and wood. J. Polymer Sci. Part C, No. 2:79-95.

Sherrod, LB., C.B. Summers, T.E. Vernor, R.C. Albin, and H.W. Parker. 1978. Mesquite for Ruminants. II. Effect of sulfur dioxide treatment upon in vitro digestibility. Texas Tech Univ. Beef Res. Rep. p. 118-138.

Tonroy, B.R., and T.W.Perry. 1974. Effect of corn preservation treatments on in vitro digestibility, ruminal $\mathrm{pH}$, and volatile fatty acid formation. $\mathrm{J}$. Anim. Sci. 38:676-680.

Topps, J.H., W.D.C. Reed, and R.C. Elliot. 1965. The effect of season and of supplementary feeding on the rumen contents of African cattle grazing subtropical herbage. J. Agr. Sci. 64:397-402.

Ulich, W.L. 1983. Development of a biomass combine. Rep. No. T-3-103, College of Agr. Sci., Texas Tech Univ., Lubbock.

United States Department of Agriculture, Soil Conservation Service. 1979. Lubbock County Soil Survey. United States Printing Office, Washington, D.C.

Ward, J.K. 1978. Utilization of corn and grain sorghum residues in beef cow forage systems. J. Anim. Sci. 46:831-840.

Weakley, D.C., and F.N. Owens. 1975. Ozone delignification. J. Anim. Sci. 41:425 (Abstract).

Weiss, R.L., B.L. Baumgardt, G.R. Barr, and V.H. Brungardt. 1967. Some influences of rumen volatile fatty acids upon carcass composition and performance in growing and fattening steers. J. Anim. Sci. 26:389-393.

Wilson, S. 1971. Some quantitative measurements of intraruminal digestion in steers. M.S. Thesis, Texas A\&M Univ., College Station.

Wood, W., and R.W. Rhodes. 1962. Effect of varying roughage of concentrate ratios on the utilization by lambs of rations differing in physical form. J. Anim. Sci. 21:479-488.

\title{
Announcing the 1985 Annual Meeting of the Society for Range Management:
}

\author{
Hotel Utah \\ Salt Lake City, Utah \\ February $11-14,1985$
}

You are invited to join the expected 1,500 range professionals who will gather in Salt Lake City, Utah, at the Hotel Utah for the 1985 Annual Meeting of the Society for Range Management. February 11 - 14, 1985. 